Columbia Law School

Scholarship Archive

\title{
Of Mutant Copyrights, Mangled Trademarks, and Barbie's Beneficence: The Influence of Copyright on Trademark Law
}

Jane C. Ginsburg

Columbia Law School, jane.ginsburg@law.columbia.edu

Follow this and additional works at: https://scholarship.law.columbia.edu/faculty_scholarship

Part of the Entertainment, Arts, and Sports Law Commons, Intellectual Property Law Commons, and the Torts Commons

\section{Recommended Citation}

Jane C. Ginsburg, Of Mutant Copyrights, Mangled Trademarks, and Barbie's Beneficence: The Influence of Copyright on Trademark Law, TRADEMARK LAW AND THEORY: A HANDBOOK OF CONTEMPORARY RESEARCH, Graeme B. Dinwoodie \& Mark D. Janis, Eds., Edward Elgar Publishing, 2008; Columbia Public LaW Research PAPER No. 07-153 (2007).

Available at: https://scholarship.law.columbia.edu/faculty_scholarship/1495

This Working Paper is brought to you for free and open access by the Faculty Publications at Scholarship Archive. It has been accepted for inclusion in Faculty Scholarship by an authorized administrator of Scholarship Archive. For more information, please contact scholarshiparchive@law.columbia.edu. 


\section{Columbia Law School}

Public Law \& Legal Theory Working Paper Group

Paper Number 07-153

\section{Of Mutant Copyrights, Mangled Trademarks, And Barbie's Beneficence: The Influence Of Copyright On Trademark Law (version of 08/20/07)}

BY:

PROFESSOR JANE C. GINSBURG

COLUMBIA LAW SCHOOL

This paper can be downloaded without charge from the Social Science Research Network electronic library at:

http://ssrn.com/abstract $=1008595$ 
Forthcoming in Graeme B. Dinwoodie and Mark D. Janis (eds.) Trade Mark Law and Theory: A Handbook of Contemporary Research (Edward Elgar Press, USA).

\title{
Of Mutant Copyrights, Mangled Trademarks, AND Barbie's BENEFICENCE: THE INFLUENCE OF COPYRIGHT ON TRADEMARK LAW
}

\author{
Jane C. Ginsburg*
}

\begin{abstract}
$\underline{\text { Abstract }}$
In Dastar Corp. v. Twentieth Century Fox Film Corp. Justice Scalia colorfully warned against resort to trademarks law to achieve protections unattainable by copyright, lest these claims generate "a species of mutant copyright law that limits the public's 'federal right to "copy and to use,", expired copyrights." The facts of that controversy, in which the claimant appeared to be invoking time-unlimited trademark protection to end-run the exhausted (unrenewed) copyright term in a motion picture, justified the apprehension that unbridled trademark rights might stomp, Godzillalike, over more docile copyright prerogatives. Unfortunately, in the Court's eagerness to forestall Darwinian disaster in intellectual property regimes, it may have engaged in some unnatural selection of its own, mangling trademark policies in the process of conserving copyright. This essay will first consider how the (mis)application of copyright precepts has distorted trademarks law, then will take up happier examples of beneficent copyright influence. The first inquiry charts the near-demise of moral rights at the hands of copyright-(mis)informed trademark analysis. The second lauds the growing acceptance of copyright-inspired free speech limitations on trademark protection, exemplified by the various "Barbie" cases, and culminating in the "fair use" exemptions of the Trademark Dilution Revision Act of 2006.
\end{abstract}

In Dastar Corp. v. Twentieth Century Fox Film Corp. ${ }^{1}$ Justice Scalia colorfully warned against resort to trademarks law to achieve protections unattainable by copyright,

\footnotetext{
* Morton L. Janklow Professor of Literary and Artistic Property Law, Columbia University School of Law. Thanks to Prof. Greg Lastowka and Prof. Graeme Dinwoodie, and for research assistance to Zahr Stauffer, Columbia Law School JD class of 2007. Portions of Part I of this article were adapted from Jane C. Ginsburg, The Right to Claim Authorship in US Trademarks and Copyright Law, 41 Hous. L. REV.. 263 (2004).

${ }^{1} 539$ U.S. 23 (2003).
} 
lest these claims generate "a species of mutant copyright law that limits the public's 'federal right to "copy and to use,”' expired copyrights." ${ }^{2}$ The facts of that controversy, in which the claimant appeared to be invoking time-unlimited trademark protection to end-run the exhausted (unrenewed) copyright term in a motion picture, justified the apprehension that unbridled trademark rights might stomp, Godzilla-like, over more docile copyright prerogatives. Unfortunately, in the Court's eagerness to forestall Darwinian disaster in intellectual property regimes, it may have engaged in some unnatural selection of its own, mangling trademark policies in the process of conserving copyright. This essay will first consider how the (mis)application of copyright precepts has distorted trademarks law, then will take up happier examples of beneficent copyright influence. The first inquiry charts the near-demise of moral rights at the hands of copyright-(mis)informed trademark analysis. The second lauds the growing acceptance of copyright-inspired free speech limitations on trademark protection, exemplified by the various "Barbie" cases, ${ }^{3}$ and culminating in the "fair use" exemptions of the Trademark Dilution Revision Act of 2006.

\section{BAD INFLUENCE}

In Dastar Corp. v. Twentieth Century Fox Film Corp., the Supreme Court announced that a work's entry into the public domain precludes resort to another federal intellectual property statute, the Lanham Trademarks Act, to achieve a de facto prolongation of exclusive copyright-like rights. Had that been all the Court held, the decision would have

\footnotetext{
${ }^{2}$ Dastar, 539 US at 34 (quoting Bonito Boats, Inc. v. Thunder Craft Boats, Inc., 489 U.S. 141, 165 (1989)).

${ }^{3}$ See Mattel, Inc. v. Walking Mountain Prods., 353 F.3d $792\left(9^{\text {th }}\right.$ Cir. 2003); Mattel, Inc. v. MCA Records, Inc., 296 F. 3d 894, 899 (9th Cir. 2002); Mattel, Inc. v. Pitt, 229 F. Supp. 2d 315, 318-19 (S.D.N.Y. 2002).
} 
been applauded, and trademark law's remedies against "false designations of origin”4 could have continued to afford a limited means for the public to be informed about the authorship of creative works. Instead, however, the Court went much farther, holding that $\S 43(a)(1)(A)$ of the Lanham Act did not address the intellectual origin of a work of authorship, but rather only the source or manufacture of physical copies of the work.

The court grounded much of its analysis in a perceived need to maintain separate domains for copyright and for trademarks, but it did not confine this discussion to copyright-expired works. Most perniciously, the Dastar Court indicated that the addition to the Copyright Act of a very circumscribed authorship attribution right in the Visual Artists Rights $\mathrm{Act}^{5}$ promotes a negative inference that VARA is the only federal law locus for attribution rights: if the trademark law afforded attribution rights, VARA would be superfluous, and "[a] statutory interpretation that renders another statute superfluous is of course to be avoided.” ${ }^{\circledR}$ But section 43(a) does not make VARA superfluous. There may be narrow areas of overlap, but VARA, in its severely constricted zone, affords a significant right that section 43(a) did not: an affirmative right to claim authorship, not merely a right to object to misrepresentations of authorship that confuse consumers as to the work's origin. VARA's beneficiaries are artists, but the beneficiaries of section 43(a) are the consuming public. Moreover, the rationales for copyright and trademarks laws are different. The former seeks to advance knowledge by stimulating creativity, the latter to aid purchasing decisions through truthful attribution of the source of goods or services. Courts addressing overlapping intellectual property claims have acknowledged that

\footnotetext{
${ }^{4}$ Lanham Federal Trademarks Act, § 43(a), 15 USC § 1125.

${ }^{5} 17$ USC § 106A.

${ }^{6}$ Dastar, 539 U.S. at 35.
} 
differently motivated laws may yield similar results when brought to bear on the same subject matter, yet one does not drive out the other. ${ }^{7}$

Given the breadth of Dastar's pronouncements about the relationship of copyright and trademarks law, it is not surprising that lower courts have understood Dastar to preclude Lanham Act claims related to the authorship attribution of works still under copyright as well as those whose copyrights have expired. ${ }^{8}$ This unflinching application

${ }^{7}$ See, e.g., Bach v Forever Living Prods., 473 F. Supp. 2d 1110 (W.D. Wa. 2007) (rejecting Dastarinspired motion to dismiss trademark passing off claim regarding unauthorized copying from JoNATHAN LIVINGSTON SEAGULL and use of one of the book's photographs as defendant's corporate logo: “trademark law protects the distinctive source-distinguishing mark, while copyright law protects the work as a whole. See Whitehead v. CBS/Viacom, Inc., 315 F. Supp. 2d 1, 13 (D.D.C. 2004). The fact that the two areas of law protect against different wrongs is reflected in the many cases in which courts have analyzed the same set of facts under both trademark and copyright law without concluding that the trademark claims were 'piggybacking' on the copyright claims [string cite omitted].”); Frederick Warne \& Co. v. Book Sales, Inc., 481 F. Supp. 1191, 1196-99 (S.D.N.Y. 1979) (stating that a publisher of children's books in the public domain could bring a trademark claim against defendant's copying of particular illustrations from the book, and commenting that "[b]ecause the nature of the property right conferred by copyright is significantly different from that of trademark, trademark protection should be able to co-exist, and possibly to overlap, with copyright protection without posing preemption difficulties"); $c$. Bonito Boats, Inc. v. Thunder Craft Boats, Inc., 489 U.S. 141 (1989) (holding that federal design patent law preempts state laws protecting against copying of boat hull designs but does not preempt state laws protecting consumers against misleading presentations of products). See also Viva R. Moffat, Mutant Copyrights and Backdoor Patents: The Problem of Overlapping Intellectual Property Protection, 19 BERKELEY TECH. L.J. 1472, 1527 (2004).

${ }^{8}$ See, e.g., Williams v. UMG, 281 F.Supp.2d 1177 (C.D.Cal.2003)(rejecting "reverse passing off" claim when film writer and director's name was left off the credits of a documentary on which he collaborated; court acknowledged that Ninth Circuit precedent had recognized such claims in similar contexts, but that Dastar now "precludes plaintiff's Lanham Act claim" in still-copyrighted as well as public domain works); Hustlers v. Thomasson, 73 U.S.P.Q.2d 1923 (N.D. Ga. 2004) (holding that Dastar's limitation of false designation of origin claims to the producer of physical copies bars not only claims by authors, but also by publishers; the court also follows Williams v. UMG Recordings in holding Dastar not limited to works in the public domain); Zyla v. Wadsworth, 360 F.3d 243, $241-51$ (1st Cir. 2004) (professor and collaborative author on a college textbook brought suit against a publisher for failing to attribute her authorship properly when she dropped out of the editing process; court read Dastar as foreclosing a Lanham Act claim based on the professor's contributions to a copyrighted textbook); Mays \& Assoc. v. Euler, 370 F.Supp.2d 362 (D. Md. 2005) (after Dastar, no Lanham Act claim for non-attribution of authorship of web design portfolio); JB Oxford \& Co. v. First Tenn. Bank Nat'l Ass'n., 427 F.Supp.2d 784 (M.D. Tenn. 2006) (no § 43(a) claim against advertiser who allegedly copied plaintiff's advertisement and substituted its name for plaintiff's).; Carroll v. Kahn, 68 U.S.P.Q.2d (BNA) 1357, 1361-62 (N.D.N.Y. 2003) (quoting Dastar and Williams v. UMG Recordings, Inc. to support dismissal of a "failure to attribute" claim); Chivalry Film Prods. v. NBC Universal, Inc., 2006 WL 89944 (S.D.N.Y. 2006) (screenwriter claimed producer of "Meet the Parents" copied his script and misattributed screenplay to third parties; court held Dastar required dismissal of misattribution claim); A Slice of Pie Prods. v. Wayans Bros. Entm't, 392 F.Supp.2d 297 (D. Conn. 2005) (same re film "White Chicks"); Beckwith Builders v. DePietri, 2006 U.S. Dist. LEXIS 67060; 81 U.S.P.Q.2d (BNA) 1302 (D.N.H. 2006) (dismissing claim that crediting building to another architect violated the Lanham Act, "Beckwith's complaint asserts that the Clark Road home was labeled with a 
of Dastar ignores the public interest concern at trademark law's core-accuracy in market information. The author's name is in fact a term that "identifies and distinguishes" goods or services, ${ }^{9}$ that allows consumers to choose among works of authorship on the basis of past experiences with other works by the same author or on the basis of the author's reputation. In other words, it functions as a trademark. ${ }^{10}$ When the public encounters the author's name, for example, on a book jacket or in film credits, it expects the work to demonstrate certain qualities. A consumer might say, “I liked So-and-So’s last novel; I think I'll try the new one.” Or “This director's films are well-regarded, I think I'll see for myself." This thought process is no different from that of the consumer who purchases shampoo by its brand name or a designer article of clothing. The producer of the shampoo or the clothing designer both endeavor to give their goods a brand image that will enable the consumer to identify the goods and relate them to his past experiences. By the same token, the author's name will convey information about the qualities of literary or artistic expression the reader/viewer/listener may expect from that author.

In confining “origin of goods” to physical goods, Dastar (and progeny) thus overlooks the role that the author's name plays in conveying information material to the

designation of origin -- via the signs placed near it. But, because the signs in front of that house accurately identified those who physically produced that tangible object [built the house, as opposed to designed it], the facts alleged by Beckwith fail to state a claim of false designation of origin under the Lanham Act.”); Sivak v Versen, 2007 U.S. Dist. LEXIS 22430 (S.D. Cal. 2007) (“Although the [Dastar] Court was examining the issue in the context of alleged misuse of material no longer protected under copyright monopoly because the copyright on the material had expired and the material had entered the public domain, the Court's analysis recognized the need to avoid 'over-extension of trademark and related protections into traditional copyright and patent areas.”).

${ }^{9}$ See Lanham Act § 45, 15 USC § 1127 (definition of “trademark’).

${ }^{10}$ For a more detailed discussion, see, e.g., F. Gregory Lastowka, The Trademark Function of Authorship, 85 B.U. L. REV. 1171 (2005); Jane C. Ginsburg, The Author's Name as a Trademark: A Perverse Perspective on the Right of "Paternity”?, 23 CARDOZO ARTS \& ENT. L. REV. 379 (2005). 
purchasing decision. This role may underlie Dastar's reference to a related claim under § 43(a). Section 43(a)(1)(B) addresses a "false or misleading description of fact, or false or misleading representation of fact, which... misrepresent[] the nature, characteristics, [or] qualities ... of his or her or another person's goods [or] services” and thus may in some instances preserve a Lanham Act right of action for some authors and performers. ${ }^{11}$ Arguably, removing the author's or the actor's name and replacing it with another's constitutes a false or misleading representation of fact (who is the author of this book; who performed in this film) that misrepresents the nature, characteristics, or qualities (authorship; performance) of the goods (the work). Note that, for purposes of section 43(a)(1)(B), the Court appears to have acknowledged that "goods" can mean a "communicative work," while, for purposes of section 43(a)(1)(A), "goods" would mean only the physical copies. Query whether it makes sense for "goods" to mean two different things in these adjacent sections. In any event, the potential availability of a section 43(a)(1)(B) claim becomes particularly significant if, after Dastar, the "origin" of copyrighted works is falsely designated only when physical copies are mislabeled as to their manufacture.

Suppose, for example, that a famous novelist grants film rights in his book. Apart from its title, the resulting movie bears only the slightest resemblance to the underlying literary work. But, recognizing the market value of the author's name, the motion picture company promotes the film (without the author's permission) as “Stephen King's The Lawnmower Man." ${ }^{12}$ Or suppose that a copyright-licensed U.S. broadcaster airs a truncated version of Monty Python's Flying Circus, presenting it as the work of the

\footnotetext{
11. $\quad$ Dastar, 539 U.S. at 38.

${ }^{12}$ See King v. Innovation Books, 976 F.2d 824, 826-27 (2d Cir. 1992).
} 
British comedy troupe even though the troupe did not approve the broadcaster's removal of approximately one-third of the content. ${ }^{13}$ In both cases, the attribution to the creators is misleading, not to say, vastly overstated. Presenting the work as "Stephen King's" when virtually the only thing in the film that is still the writer's is the title, or as "Monty Python's" when the editing has garbled it, might falsely describe the nature, characteristics, or qualities of the work. The Dastar Court indicated that a claim for false representation of the nature of the work under Section 43(a)(1(B) could lie if Dastar promoted its modestly altered videos as "quite different" from the Fox originals when they in fact are quite the same; by the same token, a claim should remain available if a work is promoted as being "by" an author when its purveyor has in fact made it "quite different” from the work the author created. ${ }^{14}$ In both cases, the purveyor has drawn attention to a commercially attractive feature of the goods (the videos' difference from the Fox original; the film's close association with an author who enjoys substantial market appeal; the television program's authorship by the comedy troupe); if this feature in fact is lacking (or is misleadingly overstated) the consuming public will have been duped. $^{15}$

\footnotetext{
${ }^{13}$ See Gilliam v ABC, 538 F.2d 14 (2d Cir.1976).

${ }^{14}$ See 4 MCCARTHY ON TRADEMARKS, § 27:77.1, at 27-149.

The Court hypothesized that if a producer of a video that substantially copied Fox's Crusade television series were, in advertising or promotion, to give purchasers the impression that the video was "quite different from that series," then Fox might have a claim for false advertising for misrepresenting the nature, characteristics or qualities of the creative content of the product in violation of $\S 43(\mathrm{a})(1)(\mathrm{B})$. That is, in this hypothetical, the defendant would be making a false statement about the content of its communicative product.

Id. (footnote omitted). McCarthy also notes that the false advertising prong contains a restriction that the "trademark prong" does not: the misrepresentation must be "in commercial advertising or promotion." Id. at 27-149 to 27-150 (internal quotation marks omitted). This is "not an insignificant limitation." Id. at 27150.

${ }^{15}$ The Stephen King and Monty Python cases could be made Dastar-comptible on another theory: the possessory credit violates $\S 43(\mathrm{a})(1)(\mathrm{A})$ not because it is a false designation of origin, but because it falsely represents "sponsorship or approval of [the defendant's] goods, services or commercial activities ..."
} 
These examples offer variants of traditional "passing off" claims that had been pursued under Section 43(a)(1)(A) (and prior versions of Section 43(a)): a version that the author claims is so altered that it no longer represents his work is nonetheless sold as if it were the real thing. Although the "goods" are a work of authorship, this is analytically akin to passing off a fake Fendi bag as though it were the genuine article. If a "false representation" claim remains viable in the case of traditional "passing off," would it also lie against one who engages in "reverse passing off"? Suppose I make copies of a Brad Meltzer legal thriller and sell them under my name. Under Dastar, I am the “origin” of the copies (or perhaps my publisher is), so a section 43(a)(1)(A) claim against me fails. But I have also made a "false representation of fact which ... misrepresents the nature, characteristics [or] qualities," that is, the authorship, of my literary work ("goods"). If Brad Meltzer can make out the remaining elements of a claim for "misrepresent[ations of] the nature, characteristics, [or] qualities," then the effects of Dastar might be blunted. ${ }^{16}$

This analysis, however, may suggest too simple a sleight of hand: next time, all an author need do is plead § 43(a)(1)(B) instead of § 43(a)(1)(A). Not surprisingly, at least one lower court has perceived a § 43(a)(1)(B) claim to be a mere end-run around Dastar, and, accordingly rejected it. In Antidote Int'l Films v Bloomsbury Pubishing PLC, ${ }^{17}$ the plaintiff, a film producer, had purchased an option to produce a motion picture based on the novel SARAH, by the elusive cult writer J.T. Leroy, whose personal history

(emphasis supplied). Dastar itself, however, invites application of $\S 43(\mathrm{a})(1)(\mathrm{B})$; a false "sponsorhip or approval" claim would not redress the wrongful conduct at issue when an entrepreneur purveys goods as being "quite different" when they are in fact quite the same.

${ }^{16}$ See, e.g., Croson v Eslinger, 455 F. Supp. 2d 256 (S.D.N.Y. 2006) (declining to dismiss § 43(a)(1)(B) claim that film's credits wrongly credited defendant as producer).

17467 F. Supp. 2d 394 (S.D.N.Y. 2006). 
outstripped the adventures of his fictional characters. It turns out, however, that "J.T. Leroy” was also a fiction, concocted by the actual author, her family, and the publisher. In response to the plaintiff's false advertising claim, the court held: “in the instant case, with respect to claims that sound in false authorship, the holding in Dastar that the word 'origin’ in $\S 43(\mathrm{a})(1)(\mathrm{A})$ refers to producers, rather than authors, necessarily implies that the words 'nature, characteristics, [and] qualities' in $\S$ 43(a)(1)(B) cannot be read to refer to authorship. If authorship were a 'characteristic[]' or 'qualit[y]' of a work, then the very claim Dastar rejected under $\S$ 43(a)(1)(A) would have been available under $\S$ 43(a)(1)(B).”

The Antidote court's critique, however, overlooks the consumer protection focus of $\S 43(a)$. Section 43(a), unlike $\S 32$ of the Lanham Act, does not require that the claimant be a trademark registrant. This is because $\S 43(a)$ targets a wider range of deceitful marketplace activity, including misleading imitation of unregistered trade dress, and false advertising. The objective is not primarily to create new rights for unregistered merchants, but to protect the public. ${ }^{18}$ This in turn suggests that the application of $\S$ 43(a)(1)(B) to misrepresentations regarding the "nature," et cetera, of "communicative goods" should be limited to misrepresentations material to the consumer. ${ }^{19}$ As suggested

\footnotetext{
${ }^{18}$ See McCarthy ON TRAdemarks. § 27:14, at 27-25 to 27-27.

The courts have nearly unanimously held that $\S 43(a)$ provides a federal vehicle for assertion of infringement of even unregistered marks and names. As the Second Circuit remarked, § 43(a) "is the only provision in the Lanham Act that protects an unregistered mark" and "Its purpose is to prevent consumer confusion regarding a product's source ...."

Id. (footnote omitted) (quoting Centaur Communications, Ltd. v. A/S/M Communications, Inc., 830 F.2d 1217, 1220 (2d Cir. 1987)).

${ }^{19}$ See of $\S 43(a)(1)(B)$ (plaintiff author must show that the misrepresentation of the nature, characteristics or qualities of her goods - work of authorship - was made in commercial advertising or promotion; the caselaw on false advertising distinguishes non actionable "puffery" from misrepresentations that the consumer is likely to believe, see, e.g., Clorox Co. Puerto Rico v Proctor \& Gamble Commercial Co., 228 F.3d 24 ( $1^{\text {st }}$ Cir. 2000).
} 
above, knowing who is the actual creator generally is material to the purchasing decision. This observation may also be key to resolving the potential tension in the post-Dastar treatment of copyrighted and public domain works.

Dastar and progeny's equation of conduct permissible under the copyright law with activities permissible under trademark law gives rise to additional consumer-unfriendly anomalies. Consider this instance of copyright-permissible material deception: copyright does not protect the ideas, information, or processes that a work discloses. As a result, copyright protection for a work such as a cookbook is typically "thin," covering the chef's literary flourishes, but not the culinary preparations themselves. As a matter of copyright law, therefore, I am free to publish my own cookbook appropriating the ingredients and following the steps needed to produce Nigella Lawson's latest creations. Moreover, because U.S. copyright law says nothing about how I label the unprotected material that I copy, any express or implied fair use obligation to credit one's sources would not extend to mere copying of public domain elements. Nonetheless, copyright's free pass on copying should not also mean that no law will prohibit me from representing that the gastronomy I describe is of my own devising. Section 43(a)(1)(B), with its focus on consumer protection, should supply that prohibition.

But, even if authorship is or can be a "characteristic" of the work, the section 43(a)(1)(B) violation does not occur unless the misrepresentation takes place in "commercial advertising or promotion."20 Simply mislabeling and selling the work without advertising the name substitution may not constitute "promotion"; the statutory text suggests that the mislabeler has called attention to the false information. One might

\footnotetext{
${ }^{20}$ Lanham Act § 43(a)(2), 15 U.S.C. § 1125(a)(1)(B) (2000).
} 
expect that there would be no market for an unpromoted work, so that in most instances the requisite "commercial advertising or promotion” will occur. But the promotion might not always go to the alleged false representation. For example, if a miscredited actor did not perform in a featured role, his (or his false substitute's) name might not appear on posters and advertisements for the film. In those instances, it is not clear that the spurned performer will have a claim. On the other hand, it may also be questionable whether the misrepresentation of a tertiary actor's name is material to consumer choice. By contrast, scholarly publications afford one area in which mislabeling may matter to the consumer, but the "commercial advertising or promotion" criterion may not be met. If the senior coauthor takes sole credit for the scholarly article, the junior participants may have no legal redress, either as a matter of the Lanham Act, or as a matter of copyright law, because coauthors cannot infringe their own joint copyright. ${ }^{21}$

The sparse caselaw on the copyright management information provision included in the 1998 Digital Millennium Copyright Act (DMCA) ${ }^{22}$ offers another disturbing illustration of the unfortunate emanations of Dastar. In this instance, we are seeing a

\footnotetext{
${ }^{21}$ Though, in the absence of a contract to the contrary, they do have a duty to account to each other for the profits of their unilateral exploitation. See, e.g., Thomson v Larson, 147 F.3d 195, 199 (2d Cir.1998) ("Joint authorship entitles the co-authors to equal undivided interests in the whole work-in other words, each joint author has the right to use or to license the work as he or she wishes, subject only to the obligation to account to the other joint owner for any profits that are made.”). If one co-author creates a new work without the other, the former co-author is not entitled to exploit the work in which he did not participate. Moreover, copying that work without crediting its author is unlikely to be considered fair use, even if the copying was done in an academic setting. See Weissmann v. Freeman 868 F.2d 1313, 1324 (2d Cir. 1989).

2217 USC §1202, defines copyright management information to include any of the following information conveyed in connection with copies or phonorecords of a work or performances or displays of a work, including in digital form, except that such term does not include any personally identifying information about a user of a work or of a copy, phonorecord, performance, or display of a work:

(1) The title and other information identifying the work, including the information set forth on a notice of copyright.

(2) The name of, and other identifying information about, the author of a work.

(3) The name of, and other identifying information about, the copyright owner of the work, including the information set forth in a notice of copyright. ...
} 
kind of boomerang effect: Dastar sought to purge trademarks law of impure copyright influences, and in so doing largely nullified interpretations of the Lanham Act that would (partially) advance authors' attribution interests. The copyright management information provision protects against the removal or alteration of information identifying a work's author, copyright owner, and/or terms and conditions of licenses, in order to promote electronic commerce by ensuring the reliability of the identifying information. ${ }^{23}$ The provision thus can play an indirect role in protecting attribution interests. ${ }^{24}$ In IQ Group, Ltd. v. Wiesner Publishing, $L L C,{ }^{25}$ the court ruled that a service mark consisting of the plaintiff company’s logo could not be protectable "copyright management information" because Dastar "cautioned against blurring the boundaries between trademark law and copyright law.” Although the logo identified the copyright owner, and thus came literally within the terms of the DMCA, "[t]he problem is that this construction allows a trademark to invoke DMCA protection of copyrights, eliminating the differentiation of trademark from copyright that is fundamental to the statutory schemes. If every removal or alteration of a logo attached to a copy of a work gives rise a cause of action under the DMCA, the DMCA becomes an extension of, and overlaps with, trademark law. ... This construction of the DMCA would allow trademarks to invoke DMCA provisions meant to protect copyrights. . . [T]his turns the DMCA into a species of mutant trademark/copyright law, blurring the boundaries between the law of trademarks and that

\footnotetext{
${ }^{23}$ See Jane C. Ginsburg, Copyright Legislation for the “Digital Millennium," 23 COLUM. VLA J.L. \& ARTS 137, 157 (1999).

${ }^{24}$ See, e.g., Justin Hughes, Art and the Law: Suppression and Liberty, The Line Between Work and Framework, Text and Context, 19 CARDOZO ARTS \& ENT L.J. 19, 21 (2001) ("the copyright management information provisions of the DMCA effectively create a right of attribution in the Internet environment”).

${ }^{25} 409$ F. Supp. 2d 587 (D.N.J. 2006).
} 
of copyright.”26 Thus, in this instance of Dastar gone feral, not only must trademark law not further copyright interests, but a copyright provision enacted to secure identifying information must not be interpreted to advance that goal if the identifying information happens to be a trademark.

Fortunately, the mangling of federal trademarks law, related false advertising law, and even para-copyright law by over-vigilant overseers of the copyright genome seems principally to concern authors' (tenuously extant) moral rights of attribution (and, perhaps, integrity). ${ }^{27}$ Recent judicial and legislative developments afford a happier example of copyright's recent influence on trademarks law: the growing recognition of free speech-based limitations on the scope of trademarks protection.

\section{GOOD INFLUENCE}

Some years ago, the caselaw on trademark parodies and similar unauthorized “speech" uses of trademarks could have led one to conclude that judges had no sense of humor (or, perhaps, that the Lanham Act cramped whatever sense of fun a judge may have indulged off the bench). ${ }^{28}$ Over time, however, courts began to leaven likelihood of confusion analyses with healthy skepticism regarding consumers' alleged inability to

\footnotetext{
${ }^{26} 409$ F. Supp.2d at 592.

27 For an analysis of Dastar's broader impact on state law passing-off claims, see Tom W. Bell, Misunderestimating Dastar: How the Supreme Court Unwittingly Revolutionized Copyright Preemption, 65 MD. L. REV. 206 (2006).

${ }^{28}$ See, e.g., Gucci Shops, Inc. v. R. H. Macy \& Co., 446 F. Supp. 838 (S.D.N.Y. 1977) (“Gucchi Goo” diaper bags held likely to be confused with Gucci handbags); Mutual of Omaha Insurance Co. v. Novak, 836 F.2d 397 (8th Cir. 1987) ("Mutant of Omaha" anti-nuclear protest items such as coffee mugs and posters held likely to be confused with "Mutual of Omaha" insurance services; Anheuser-Busch, Inc. v. Balducci Publications, 28 F.3d 769 (8th Cir. 1994) ("Michelob Oily" parody ad in SNICKER humor magazine held likely to confuse the public as to its approval by the producers of Michelob Dry beer); Harriette K. Dorson, Satiric Appropriation and the Law of Libel, Trademark and Copyright: Remedies Without Wrongs, 65 B.U.L. REV. 923 (1985).
} 
perceive a joke. $^{29}$ They even suggested that the first amendment might require a more persuasive showing of likely confusion when expressive works were alleged to infringe. ${ }^{30}$ These decisions did not always expressly cite the copyright fair use defense, but the considerations underlying the copyright doctrine seemed to inform trademark analysis as well. ${ }^{31}$ The spillover effect may indeed have been inevitable, as several of the cases in which the fair use defense prevailed coupled copyright and trademark claims; it is not surprising that the sardonic expressions that proved fair use for the copyright goose would lead to similar treatment for the trademarks gander, particularly when the avian species at issue was a bird called Barbie.

Lawful unauthorized uses of trademarks of course predate both the Mattel toy company and the Lanham Act. In 1924, in a case concerning the labeling of lawfully purchased and rebottled perfume, Justice Holmes famously declared "When the mark is used in a way that does not deceive the public we see no such sanctity in the word as to prevent its being used to tell the truth. It is not taboo.,32 Lanham Act $\S 33(b)(4)$ codified part of this precept by permitting the use of descriptive terms in a registered trademark for the purpose of description, and not as a trademark. For example, if ZEST is a

\footnotetext{
${ }^{29}$ See Cliffs Notes, Inc. v. Bantam Doubleday Dell Publishing Group, Inc. 886 F.2d 490 (2d Cir. 1989) ("Spy Notes" parody of Cliffs Notes, no likelihood of confusion found); Yankee Publishing v. News America Publishing, 809 F. Supp. 267 (S.D.N.Y. 1992) (New York Magazine parody of cover of Old Farmer's Almanac cover, no likelihood of confusion found); Louis Vuitton Malletier S.A. v. Haute Diggity Dog, LLC, 464 F. Supp.2d 495 (E. D. Va. 2006) ("HDD sells products such as Chewnel \# 5, Dog Perignon, Chewy Vuiton, and Sniffany \& Co. in pet stores, alongside other dog toys, bones, beds, and food, and most are priced around \$ 10;” neither likelihood of confusion nor dilution found).

${ }^{30}$ Rogers v Grimaldi, 875 F.2d 994, 999 (2d Cir. 1989).

${ }^{31}$ See Pierre N Leval, Trademark: Champion of Free Speech, 27 ColuM. J.L. \& ARTS 187, 208 (2004) (in federal anti dilution act Congress is saying to courts, "You have shown in your development of fair use in copyright that you know how to limit the scope of a broadly-written exclusivity statute - to keep it in line with the needs of free expression. We are relying on you to do that here. Create appropriate doctrines of "fair use" to keep the Dilution Act within reasonable bounds.").

32 Prestonettes, Inc. v. Coty, 264 U.S. 359, 368 (1924). See also Champion Spark Plug v Sanders, 331 U.S. 125 (1947).
} 
trademark for a lemon-lime soda, the registrant cannot prohibit a competitor from informing the public that its lemon-lime soda, FIZZUP, includes lemon zests, or that it has a zesty taste. But $\S 33(b)(4)$ does not explicitly exempt a competitor's use of ZEST to describe the competitor's product, for example, to proclaim that FIZZUP tastes better than, has more bubbles than, or fewer calories than, ZEST. Nor does § 33(b)(4) explicitly allow a non competitor, such as the (fictitious) magazine Teen Taste to elicit its readers' beverage preferences by asking them whether ZEST is their most or least favorite soda pop. Judge Kozinski dubbed these latter denominations "nominative fair use," and the sobriquet has stuck. ${ }^{33}$ The nominative fair use defense to trademark infringement proceeds through an analysis of factors. "First, the plaintiff's product or service in question must be one not readily identifiable without use of the trademark; second, only so much of the mark or marks may be used as is reasonably necessary to identify the plaintiff's product or service; and third, the user must do nothing that would, in conjunction with the mark, suggest sponsorship or endorsement by the trademark holder." ${ }^{34}$ As we will see, these factors complement and echo the first, third, and fourth copyright fair use factors. ${ }^{35}$

Although copyright is a property "right in gross," and trademark is not (or is not supposed to be), the trademark and copyright fair use limitations have this in common: the users of the mark or of another author's work are engaged in independent economic

\footnotetext{
${ }^{33}$ See New Kids on the Block v. News Am. Publ'g, 971 F.2d 302 (9 $9^{\text {th }}$ Cir. 1992); Playboy Enterprises, Inc. v. Welles, 279 F.3d 796 (9th Cir. 2002); Century 21 Real Estate Corp. v. Lendingtree, Inc., 425 F.3d 211 (3d Cir. 2005) (following Ninth Circuit). Other circuits reach the same result through similar reasoning, albeit without applying the label "nominative fair use." See, e.g., Universal Commun. Sys. v. Lycos, Inc., 478 F.3d 413, 424-25 ( $1^{\text {st }}$ Cir. 2007). See generally J. Thomas McCarthy, Non-Confusing Nominative Fair Use, 4 MCCARTHY ON TRADEMARKS AND UNFAIR COMPETITION § 23:11 (4th ed.).

${ }^{34}$ New Kids, 971 F.3d at 306.

${ }^{35}$ See 17 USC § 107(1), (3), (4).
} 
or creative activity. They are not simply redistributing another's work of authorship ${ }^{36}$ or appending another's mark to the same or confusingly similar goods that the mark owner has not produced. Rather, they are making a new work, or promoting their own goods or communicative activities. ${ }^{37}$ By the same token, the uses do not unfairly usurp the copyright or trademark owner's markets. A devastating review may dampen desire for the critiqued work, but that kind of harm is not cognizable in copyright. ${ }^{38}$ Similarly, a comparative advertisement may persuade consumers of the superior merits of the competitor's goods or services, but if the advertisement is truthful no Lanham Act claim lies. $^{39}$

Trademark "fair use" may have received its greatest impetus from decisions involving overlapping claims of copyright and trademark infringement, for it is not surprising that once a court has found the use to be "transformative" and to promote speech and/or learning, and thus to be "fair" in the copyright sense, that court is unlikely to find the same activity to violate the copyright holder's trademark in the copied work. Nonetheless, the first of the "Barbie" cases to find trademark fair use did not involve copyright infringement, though it did concern a parody. ${ }^{40}$ In that case, the song "Barbie Girl” by the Danish one-hit (at least in the US) group “Aqua” in 1997 foisted on the

\footnotetext{
${ }^{36}$ In narrow circumstances of "market failure," redistributive uses may be ruled "fair," but the kinds of uses at issue in the copyright/trademark overlap cases are more traditionally "transformative," such as parodies.

${ }^{37}$ Fair use of another's trademark to describe the trademark owner's goods, as lawfully repackged and resold by the defendant (the situation, for example, in Prestonettes), does not, admittedly, involve the same kind of independent economic activity. Permitting the use of the mark, however, is a necessary corollary to the "exhaustion" or "first sale" doctrine, which permits third parties to resell trademarked (or copyrighted) goods once they have been lawfully sold. If the reseller cannot inform the public what the resold goods are, the exhaustion doctrine will, as a practical matter, have little impact. Cf. Kellogg Co. v. National Biscuit Co., 305 US 111, 118 (1938) (once patent expired, and competitors are free to manufacture the goods, they also are entitled to call the goods "the name by which [they] had become known").

${ }^{38}$ See, e.g., Campbell v Acuff-Rose Music, 510 U.S. 569, 593 (1994).

${ }^{39}$ See, e.g., Smith v. Chanel, Inc., 402 F.2d 562 (9th Cir.1968) (smell-alike perfume); August Storck K.G. v. Nabisco, Inc., 59 F.3d 616 (7th Cir.1995) (competing candies)

${ }^{40}$ Mattel, Inc. v. Universal Music International, 296 F.3d 894 (9th Cir. 2002).
} 
airwaves lyrics like the following, nasally sung to a catchy refrain: “I'm a Barbie girl, in a Barbie world. Life in plastic, it's fantastic. You can brush my hair, undress me everywhere. Imagination, life is your creation. . . . I'm a blond bimbo girl, in a fantasy world. Dress me up, make it tight, I'm your dolly.” To which the bass in the group would interject in a froggish croak (Aqua's album was, after all, called "Aquarium”): “C’mon Barbie, let’s go party!”

Holding that "the trademark owner does not have the right to control public discourse whenever the public imbues his mark with a meaning beyond its sourceidentifying function, ${ }^{, 41}$ the Ninth Circuit rejected both the likelihood of confusion and the dilution claims. Following Second Circuit precedent, the Ninth Circuit balanced the "public interest in free expression" against the "public interest in avoiding consumer confusion,” and accorded the former decisive weight unless the song title’s appropriation of Barbie "has no artistic relevance to the underlying work whatsoever, or, if it has some artistic relevance, unless the title explicitly misleads as to the source or the content of the work." ${ }^{42}$ Observing that the Barbie doll was the target of the song, the court held the group was entitled to identify the butt of its joke, and had done nothing to mislead the public into thinking that Mattel authorized the song. The court dismissed the dilution claim on the ground that the 1996 Federal Trademark Dilution Act's exception for "noncommercial uses" should be construed to include parodies.

The other Barbie trademark fair use decision challenged irreverent (to say the least) presentations of Barbie dolls, and thus implicated both copyright (the reproduction right in the image of the dolls) and trademarks (use of the Barbie name in the titles of the

\footnotetext{
${ }^{41} 296$ F.3d at 900.

${ }^{42}$ Id at 902, citing Rogers v. Grimaldi, 875 F.2d 994, 999 (2d Cir. 1989).
} 
photographs). The extensive analysis of copyright fair use almost certainly drove the subsequent findings of unlikelihood of confusion and non dilution. In Mattel, Inc. v. Walking Mountain Prods., ${ }^{43}$ the producer of Barbie tried to enjoin an artist from distributing his series, "Food Chain Barbie" which depicted Barbie victimized by a variety of kitchen appliances (and appearing occasionally to enjoy it). In granting summary judgment on the copyright claim, the court ruled on the first fair use factor (purpose and character of the defendant's use) that the Food Chain series "parod[ies] Barbie and everything Mattel's doll has come to signify. Undoubtedly, one could make similar statements through other means about society, gender roles, sexuality, and perhaps even social class. But Barbie, and all the associations she has acquired through Mattel's impressive marketing success, conveys these messages in a particular way that is ripe for social comment." ${ }^{44}$ On the third factor (amount and substantiality of the taking), the court stressed that parodies need not restrict themselves "to take the absolute minimum amount of the copyrighted work possible," and thus that, in context, reproducing the entire doll did not undermine the fair use defense. ${ }^{45}$ On the fourth factor (harm to potential market for the work), the court found it unlikely that Mattel would enter the market for "adult-oriented artistic photographs of Barbie.”46

The Ninth Circuit approvingly cited another Barbie copyright parody decision, Mattel, Inc. v. Pitt, ${ }^{47}$ in which the defendant's "dungeon doll" website offered to customize Barbie dolls in a variety of dominatrix modes, such as a "'Lederhosen-style'

\footnotetext{
${ }^{43} 353$ F.3d 792 (9 $9^{\text {th }}$ Cir. 2003).

${ }^{44}$ Id. at 802.

${ }^{45} \mathrm{Id}$. at 804.

${ }^{46}$ Id. at 806 .

${ }^{47} 229$ F. Supp. 2d 315 (S.D.N.Y. 2002).
} 
Bavarian bondage dress and helmet in rubber with PVC-mask and waspie." ${ }^{\text {48 }}$ The differently accessorized dolls arguably violated Mattel's exclusive right to create derivative works based on Barbie, and the website's photographs allegedly violated the reproduction right. The Southern District of New York considered the statutory fair use factors, and ruled the defendant's use and context of Barbie sufficiently transformative and unlikely to supplant one of Mattel's markets for the work. "A different analysis would apply if Defendant had, for example, dressed Barbie dolls in a different style of cheerleader outfit than those marketed by Mattel. To the Court's knowledge, there is no Mattel line of "S\&M” Barbie.",49

Having held defendant's use to be "fair" as a matter of copyright law, notably because of the expressive values the parody advanced, the Ninth Circuit effectively sealed the fate of the trademark and dilution claims. When Mattel offered a survey to rebut the copyright fair use argument that the Food Chain series was parodic, the court rebuffed it, ruling that a work's parodic character is objectively determined, that public perception is irrelevant. ${ }^{50}$ Curiously, the court did not address the survey in its trademark analysis, even though public perception normally is highly relevant to the assessment of likelihood of confusion. Rather, with respect to Food Chain's incorporation of Barbie in the title of the series, the court relied on its prior decision in the Barbie Girl song case to reject a likelihood of confusion claim. With respect to Food Chain's alleged violation of Mattel's trade dress rights by reproducing the Barbie figure (largely undressed), the court ruled the copying nominative fair use. "Forsythe used

\footnotetext{
${ }^{48} I d$. at 322.

${ }^{49}$ Id.

50353 F.3d at 801 ("The issue of whether a work is a parody is a question of law, not a matter of public majority opinion.”).
} 
Mattel's Barbie figure and head in his works to conjure up associations of Mattel, while at the same time to identify his own work, which is a criticism and parody of Barbie. Where use of the trade dress or mark is grounded in the defendant's desire to refer to the plaintiff's product as a point of reference for defendant's own work, a use is nominative."51 "Conjure up,” notably, is a standard formulation of the minimum extent of copying that the copyright fair use caselaw permits in a parody. ${ }^{52}$ Not surprisingly, then, the court's analysis of the second nominative fair use factor - whether defendant used only so much of a trademark or trade dress as is reasonably necessary -- echoed its treatment of the third copyright fair use factor. ${ }^{53}$ By the same token, having found as a matter of copyright law that the defendant was not usurping a potential market - "adult" photos -- that Mattel was likely to enter, the court ruled on the third nominative fair use factor that "it is highly unlikely that any reasonable consumer would have believed that Mattel sponsored or was affiliated with [defendant's] work. ${ }^{54}$ Finally, on the dilution claim, the court again relied on "Barbie Girl" to hold "Food Chain" noncommercial within the meaning of the Federal Trademark Dilution Act, and thus not actionable. ${ }^{55}$

Congress has recently endorsed the judicially-devised nominative fair use limitation, and the resulting exclusion of parodies from the ambit of the dilution claim. In the Trademark Dilution Revision Act of 2006, ${ }^{56}$ Congress reaffirmed its expansion of

\footnotetext{
${ }^{51} I d$. at 810.

${ }^{52}$ Id. at 800, citing Dr. Seuss Enters., L.P. v. Penguin Books USA, Inc., 109 F.3d 1394, 1400 (9 $9^{\text {th }}$ Cir. 1997).

${ }^{53} \mathrm{Id}$. at 811.

${ }^{54} \mathrm{Id}$. at 812.

${ }^{55}$ Cf. 17 U.S.C. § 107(1) (copyright fair use factor takes commercial nature of use into account in assessing the "nature and purpose" of the use)

${ }^{56}$ HR 683, $109^{\text {th }}$ Cong., 2d sess. (2006), --- P.L. ---
} 
trademarks law in the 1995 Federal Trademarks Dilution $\mathrm{Act}^{57}$ to protect famous marks, even in the absence of likelihood of confusion, thus continuing to afford famous marks a scope of coverage more akin to a property "right in gross" than the traditional protection limited to remedying likelihood of deception or confusion. ${ }^{58}$ To defuse the potential conflict between invigorated trademarks and expressive interests, Congress set out broad "exclusions," of which the first is "Any fair use, including a nominative or descriptive fair use, or facilitation of such fair use of a famous mark by another person . .."59 The language is striking, because the terms "fair use” and "nominative fair use," though now familiar from the caselaw, ${ }^{60}$ do not elsewhere appear in the statute. Nor does "descriptive fair use” as such, although section 33(b)(4) provides a defense regarding "a term or device which is descriptive of and used fairly and in good faith only to describe the goods or services of such party, or their geographic origin.”61 In other words, Congress appears to have taken trademark fair use as a given, perhaps even as a kind of omnipresence brooding over both copyright and trademark rights. As in the Copyright Act, the revised anti-dilution statute does not purport to create fair use; it restates it, in very open-ended fashion. $^{62}$

The statute illustrates the kinds of uses that qualify as trademark fair uses, by providing that fair uses "includ[e] use in connection with -

\footnotetext{
${ }^{57}$ Federal Trademark Dilution Act of 1995, 15 USC § 1125(c).

${ }^{58}$ On the dilution claim and its contrast with traditional trademark norms, see generally, Robert G. Bone, Hunting Goodwill: A History of the Concept of Goodwill in Trademark Law, 86 B. U. L. REV. ---, (2006); Mark A. Lemley, The Modern Lanham Act and the Death of Common Sense, 108 YALE L. J. 1687 (1999). On federal dilution's less impressive record in the courts, see Clarisa Long, Dilution, 106 Colum. L. Rev. 1029 (2006).

5915 U.S.C. $\S 1125(c)(3)(A)$. See also H.R. Rep. No.109-23, $109^{\text {th }}$ Cong., $1^{\text {st }}$ sess. (2005) at 25 (Statement of Rep. Berman).

${ }^{60}$ See, e.g., decisions cited supra note

${ }^{61} \S 1115(\mathrm{~b})(4)$.

${ }^{62}$ See infra note 60.
} 
(i) advertising or promotion that permits consumers to compare goods or services, or

(ii) identifying and parodying, criticizing, or commenting upon the famous mark owner or the goods or services of the famous mark owner." ${ }^{33}$

Congress codified these fair use concepts in less detail than its codification of copyright fair use in $\S 107$ of the 1976 Copyright Act but in a manner which, with its two “includings," beckons further judicial intervention. The 2006 Congress thus appears to share the 1976 Congress' disinclination to "freeze" fair use, but instead to leave courts "free to adapt the doctrine to particular situations on a case by case basis." ${ }^{44}$ Moreover, while Congress endorsed these judge-made limitations in the context of the Dilution Revision Act, it would seem that they remain equally pertinent in the traditional, confusion-based, trademark actions in which courts initially applied them. Trademark fair use, then, shows us that copyright concepts and methodologies can salubriously influence trademarks law, not by cordoning copyright off from trademarks, as in Dastar, but by recognizing and drawing the best from the overlap in subject matter and (where relevant) in the rationale for extending or denying protection.

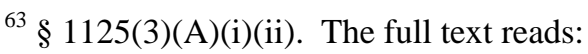

(3) Exclusions. The following shall not be actionable as dilution by blurring or dilution by tarnishment under this subsection:

(A) Any fair use, including a nominative or descriptive fair use, or facilitation of such fair use, of a famous mark by another person other than as a designation of source for the person's own goods or services, including use in connection with--

(i) advertising or promotion that permits consumers to compare goods or services; or

(ii) identifying and parodying, criticizing, or commenting upon the famous mark owner or the goods or services of the famous mark owner.

(B) All forms of news reporting and news commentary.

(C) Any noncommercial use of a mark.

It is worth noting that the second and third categories of exclusions involve the kinds of uses that the copyright act considers susceptible to being ruled "fair," see the preamble to 17 USC § 107.

${ }^{64}$ See House Report 94-1476, 94 ${ }^{\text {th }}$ Cong., 2d. sess. (1976) at 66 ("there is no disposition to freeze the doctrine in the statute, ... Beyond a very broad statutory explanation of what fair use is and some of the criteria applicable to it, the courts must be free to adapt the doctrine to particular situations on a case by case basis. Section 107 is intended to restate the present judicial doctrine of fair use, not to change, narrow, or enlarge it in any way.”). 